\title{
Quevedo testigo y actor de la política española de las primeras décadas del siglo XVII: España defendida y Grandes anales de quince días
}

\author{
Victoriano Roncero \\ Stony Brook University \\ Hispanic Languages \& Literature \\ College of Arts \& Sciences \\ N3015 Melville Library, Stony Brook, \\ NY 11794 (EE. UU.) \\ victoriano.roncero-lopez@stonybrook.edu
}

[La Perinola, (Issn: 1138-6363), 21, 2017, pp. 41-66]

DOI: $10.15581 / 017.21 .41-66$

El movimiento humanista florentino desde principios del siglo $\mathrm{xv}$ se caracterizó por un enorme sentido cívico: Leonardo Bruni, Poggio Bracciolini, Coluccio Salutati o Nicolás Maquiavelo, este último ya a finales de la centuria, combinaron sus estudios filológico-históricos con su participación en la vida pública de su ciudad. Recordemos que, por ejemplo, Bruni, Bracciolini o Maquiavelo fungieron como cancilleres de la República de Florencia, incluso uno de ellos, Bracciolini, desempeñó el cargo de secretario apostólico de Bonifacio IX. Eso no les alejó en absoluto de su actividad como historiadores o literatos: Historiarum Florentini populi libri XII, Facezie, Il principe, Discorsi sopra la prima deca di Tito Livio o Mandragola testimonian ese interés de servicio público $\mathrm{y}$, al mismo tiempo, el de la transmisión de saberes históricos o de entretenimiento literario. Con el paso del tiempo el Humanismo se fue centrando en su vertiente filológica, pero aun así en ciertos momentos recuperó el interés por la ciencia política, extraída a veces de los textos clásicos, del que que tenemos un magnífico ejemplo en Politicorum sive civilis doctrina libri sex de Justo Lipsio, cuya primera edición salió a la luz en Leyden en 1589, y que pronto fue traducida al español por Bernardino de Mendoza y publicada en Madrid en 1604 por Juan Flamenco. En el primer capítulo de la obra Lipsio expone claramente su intención:

He propuesto enseñar al príncipe cómo podrá entrar y caminar rectamente por la senda de la vida civil, y sin desviarse llegar al cabo de ella; no por 
preceptos míos, mas por los avisos y aun las mismas palabras de los antiguos (Lipsio, Políticas, p. 9).

El humanista belga recoge, pues, el espíritu didáctico de ciertos teóricos clásicos para crear un «espejo de príncipes» aplicable a los monarcas y gobernantes europeos de los siglos xVI y xVII. Por lo tanto, su acercamiento a la política se produce desde la filología, pues se hallan ya lejanos los años del «humanismo cívico» de los florentinos.

Quevedo participa también de esta vertiente teórica (no olvidemos que conocía la obra de Lipsio con el que incluso mantuvo correspondencia epistolar $)^{1}$, desde los primeros momentos de su producción; su Discurso de las privanzas fue redactado entre 1606 y 1608 (Díaz Martínez, 2000, pp. 53-58). Este interés continuó en la década siguiente con la primera parte de Política de Dios, publicada por primera vez en 1626, pero redactada en 1616, según afirma el propio escritor ${ }^{2}, y$ culminó en el año 1644 con la publicación de Primera parte de la vida de Marco Bruto, ya escrita en 1631, aunque pudo revisar el texto hasta su entrega a la imprenta trece años después ${ }^{3}$. Según estos textos, don Francisco era plenamente consciente de la importancia de la escritura de manuales del buen gobernante en los que, siguiendo la estela de su admirado Justo Lipsio, se enseñaba, tanto a los monarcas como a sus ministros el arte del buen gobierno.

Su relación con los humanistas florentinos citados no se limita a esta actividad de tratados politicos, sino que, como vamos a ver, se extiende también al campo de la historia ${ }^{4}$, más concretamente de la «historia política», concepto acuñado por Polibio en sus Historias (I, 2, 8). Este concepto del historiador griego abarcaba la narración de los hechos políticos y militares sin intención partidista o didáctica. Quevedo se enmarca en estos textos históricos en esta tradición clásica, siguiendo la senda marcada por los historiadores humanistas, que utilizaron la historia como elemento de exaltación de la patria, de acuerdo a la frase de Catón de "pugna pro patria», que como, muy bien señala Cochrane (1985, p. 218), fue

carried out with the tongue rather than the sword. Hence the task of defending the patria (against the insults of its enemies» passed from soldiers to historians, whom Giovannelli called upon «to praise and exalt» their city

1. Ver Ramírez, 1966. Para la influencia de Lipsio en Quevedo ver Lida, 1958 y Ettinghausen, 2009.

2. Así lo afirma en la dedicatoria «Al conde-duque, gran canciller, mi señor», donde afirma: «Este, señor, es el libro que yo escribí diez años ha. Hoy es mío, sin que en sus yerros tenga culpa otra mano. Dos veces le he dado a vuestra excelencia: cinco años ha, preso y en poder de la justicia; hoy, justiciado de la calumnia y en poder de la invidia» (Quevedo, Política de Dios, pp. 190-191).

3. Alonso Veloso, 2012, p. 643, afirma que «es fácil suponer que en el transcurso de esos trece años Quevedo revisó su texto, pero no hay pruebas claras».

4. Sobre este tema ver Roncero, 1991. 
by telling of its ancient beauty and greatness and the heroic deeds of its illustrious personages.

Quevedo comprendió perfectamente este rasgo fundamental de la historiografía humanista y pretendió utilizar sus narraciones históricas como instrumentos para defender no solo a su patria ${ }^{5}$, sino para exponer también sus posiciones ideológicas sobre los temas importantes de la vida política de la España de su tiempo. En este sentido, quiero demostrar cómo el escritor madrileño utiliza los textos históricos y los políticos para reflejar su pensamiento sobre las materias de estado, de la forma en que se ha de gobernar el Imperio, pero no, como podía hacerlo Justo Lipsio, desde una perspectiva teórica, sino que pretende presentarlo desde la aplicación a su contemporaneidad. Porque lo que diferencia a nuestro escritor de otros politólogos, y lo convierte en heredero de Bruni o Maquiavelo, es su interés por participar activamente en la política española de su momento. Esta dedicación a la vida política, sobre todo durante los años 1613 a 1619, durante los que sirvió como secretario y hombre de confianza del duque de Osuna, virrey primero en Sicilia y luego en Nápoles, ha llevado a algunos críticos a considerar que el interés máximo de Quevedo residía en seguir una carrera política por encima de su labor como escritor; así Serrano Poncela escribió que su obra «es el resultado de una gran frustración. Quevedo escribió porque no pudo hacer otra cosa; la cosa que él hubiera deseado con fervor: hacer alta política, no teórica precisamente, sino política pragmática, de hechos diarios, de intriga y circunstancia» (1963, p. 109).

En el mismo sentido se expresó José Luis Aranguren, para quien Quevedo

no fue solo un escritor político, sino actor político también. Él hubiera querido entregarse con toda el alma a la acción política [...] En Quevedo hay un hombre políticamente derrotado que transfiere al plano de la vida humana una actitud adoptada en el reino de la política (1950, p. 166).

Me parecen interesantes las opiniones de Serrano Poncela y de Aranguren y de otros más $^{6}$, pero me parecen equivocadas, o por lo menos exageradas, porque no toman en consideración dos aspectos importantes: el primero, ya mencionado, es el antecedente de los humanistas florentinos, anteriormente citados, que combinaron ambas actividades, y en los que el ejercicio de la una aparece reflejada en el de la otra; el segundo, y quizás aun más importante, se basa en el hecho

5. Maravall, 1982, p. 99, considera a Quevedo como «protonacionalista». Ver también sobre el tema los libros de Baum, 1970, y de Vivar, 2002. Müller, 1978, p. 221, habla del patriotismo de Quevedo como «apasionado - sombrío en su ardor, trágico en su consunción».

6. Lira Urquieta, 1958, p. 31, escribe: «Es posible que debido a su posición relativamente modesta nunca aspirara a ser el ministro omnipotente. Pero aspiró siempre a ser consejero áulico, a la manera de Antonio Pérez». 
de que Quevedo era ya un escritor de prestigio cuando decidió unirse a don Pedro Girón en Palermo: ya había escrito varios de los Sueños, el Discurso de las privanzas, la España defendida, traducido a Anacreonte, a Focílides, y las Lágrimas de Hieremías castellanas ${ }^{7}$ y varios de sus poemas habían aparecido publicados en Flores de poetas ilustres, antología recopilada por Pedro Espinosa, impresa en Valladolid el año 1605. Estos textos marcan ya las tendencias de lo que sería su producción posterior y testimonian los intereses literarios y políticos del escritor.

Estas obras demuestran ya el interés por el mundo de la política, como veremos, desde el primer momento en su producción literaria, hasta el punto de que se ha hablado de que nuestro escritor tenía un "alma política». Lo cierto es que su participación en esta actividad se inició antes de que aceptara la invitación de Osuna y en la segunda mitad de 1613 se embarcara para Sicilia para servir al Virrey, suceso que se ha atribuido a una crisis de conciencia ${ }^{9}$. Sin entrar en la discusión bizantina sobre este irresoluble tema de cuál fue su motivación para aceptar el ofrecimiento de don Pedro Téllez, me inclino a pensar que lo que acabó de decidir a Quevedo a emigrar a Italia fue la conexión ideológica entre los dos hombres: la añoranza por un pasado que consideraban mejor, más virtuoso, más glorioso para España, por una parte, y el deseo de adoptar una política y una actitud que ambos consideraban necesarias para mantener la reputación y la gloria que el Imperio había alcanzado en los reinados anteriores, por otra. Esta comunidad de pensamiento venía arropada por una larga y azarosa amistad que habría comenzado en Alcalá de Henares a finales del siglo xvi, y que incluía una posible huida a Sevilla para escapar de la acción de la justicia ${ }^{10}$.

La acción política de Quevedo, por tanto, se inició en la primera década del siglo xviI en sus primeros textos políticos con los que pretendía influir en la dirección en los asuntos de gobierno que habían instaurado Felipe III y el duque de Lerma. El monarca y su privado, siguiendo la pauta establecida por Felipe II buscaban firmar la paz con los principales enemigos de la Corona y revivir la Pax Romana con la Pax Hispanica ${ }^{11}$, proceso que culminó la Tregua de los doce años, firmada con Holanda el 7 de julio de 1609 con la reticencia de Felipe III, que esperó hasta el último momento posible para ratificar in extremis el tratado. Quevedo redactó su Discurso de las privanzas en los primeros

7. Recordemos que la dedicatoria a don Bernardo de Sandoval y Rojas, cardenal arzobispo de Toledo, está firmada en La Torre de Juan Abad el 8 de mayo de 1613.

8. González de Amezúa, 1946, p. 6.

9. Ettinghausen, 1982, p. 37, escribe: «Fueron, sin duda, estos sentimientos de mala reputación y mala conciencia uno de los motivos que le persuadieron, precisamente en ese mismo año de 1613, a marcharse de España para ir a servir en Sicilia al Duque de Osuna».

10. Ver López Ruiz, 2008, pp. 51-55.

11. Sobre el tema ver Allen, 2001. El historiador británico afirma que Felipe III no era tan pacifista como nos han dado a entender otras fuentes, sino que pretendió revertir la política pacifista de su padre, porque «quería emular a los heroicos reyes guerreros del pasado español y confirmar su reputación entre los príncipes» (p. 324). 
años del reinado del joven monarca y su privado y quiso con este texto aconsejar un cambio en la política de pactos que desarrollaban los dos gobernantes, por lo que no estoy de acuerdo con la opinión de López Ruiz (2008, pp. 50-51) de que con este texto el escritor pretendía lograr la atención de ambos personajes y elogiar la actitud pacifista de la Corte. Me parece que queda clara la intencionalidad quevediana cuando en un momento determinado de este Discurso escribe:

Hacen los enemigos cuidadosos y virtuosos a los hombres, porque los émulos y contrarios son como los cuervos, que no van sino a lo podrido y muerto sin sentir lo sano ni olerlo. ¿No es harto que al que no tiene voluntad de ser bueno le fuercen los enemigos a que lo sea? iQué fuertes, qué ejercitadas en las milicias, qué armadas, qué solicitas están las ciudades o fuertes vecinos a los enemigos!...Y por esta razón se perdió Roma cuando ella, por haber vencido a Cartago, dijo que ya estaba segura pues no tenía enemigos, a lo cual repondió Nasica que entonces estaba en mayor peligro, pues no tenía a nadie a quien temiese ni reverenciase (pp. 230-231).

La idea expuesta por don Francisco en este párrafo tiene una fuente clásica: Salustio, que en Conjuración de Catilina ya había advertido a los romanos del efecto nocivo que podía causar a Roma la ausencia de guerras; la degeneración de las costumbres acarrearía la ruina del Imperio, trastornando la sobriedad de los gloriosos antepasados:

Pero es que había entrado un afán no menor de sexo, crápula y demás refinamientos: los hombres se sometían como mujeres; las mujeres exponían su honra a los cuatro vientos; para alimentarse escudriñaban todo en la tierra y en el mar; dormían antes de tener deseo de sueño, no aguardaban a tener hambre o sed ni frío o cansancio, sino que por vicio anticipaban todas estas necesidades. Este comportamiento incitaba al crimen a la juventud cuando faltaban los bienes de familia (13, 3-4).

Quevedo no ahonda en esta ocasión en los desastres que comportarían al Imperio estos tiempos de paz con los enemigos europeos, a quienes se había enfrentado España desde el reinado de los Reyes Católicos y los Austrias mayores. Creo que esto se debe a que en el momento en que Quevedo escribió este tratado político todavía se luchaba en Flandes, en cuyos campos de batalla consiguió la gloria su amigo y protector el duque de Osuna. Por ello, no se había consumado la degradación y depravación de las costumbres que relataba el historiador latino. Pero unos meses más tarde, Quevedo inicia la redacción de España defendida, dedicada a Felipe III el 20 de septiembre de 1609. En esta obra sí se especifican los vicios en los que han caído los españoles y las españolas como consecuencia de ese ocio generado por la política pacifista que se ha promovido desde el gobierno. En el capítulo cinco de esta «laus Hispaniae» titulado «De las costumbres con que nació España y las antiguas», el escritor presenta un panorama desolador de la situación de la sociedad española de principios del siglo xvir. Después de haber 
ensalzado las virtudes de los romanos en tiempo de guerra, siguiendo de nuevo a Salustio ${ }^{12}$, así como las de los castellanos «de quinientos y de cuatrocientos años a esta parte» (p. 174) ${ }^{13}$, pasa a describir algunos de los vicios que dominan a los habitantes de la corte madrileña; la codicia: «Alcanzan a todas partes las fuerzas del dinero [...] conquistamos riquezas ajenas; ricos, las mismas riquezas nos conquistan. ¿A qué vicio no ha abierto la puerta con llave de oro la avaricia?» (p. 175); la gula: «Muchos en este tiempo entierra la gula. iQué más fea y más contra naturaleza, guisar muerte para sí del sustento natural!» (p. 175); el juego: «Otros, del juego, que fue a moderados ánimos entretenimiento, hicieron oficio» (p. 175).

La enumeración de las amoralidades de los españoles continúa con el excesivo gasto del adorno por parte de las mujeres, por lo que «su hermosura es tan costosa y de tanto daño a España, que sus galas nos han puesto necesidad de naciones extranjeras para comprar, a precio de oro y plata, galas y bujerías, a quien sola su locura y devaneo pone precio» (p. 176). A este vicio hay que añadir el del afeminamiento de los varones, en quienes las galas «parecen arrepentimiento de haber nacido hombres, y otros pretenden enseñar a la naturaleza cómo sepa hacer de un hombre mujer» (p. 177). Para finalizar, Quevedo hace referencia al adulterio de las mujeres y a la abundancia de maridos consentidos, de cornudos, que han convertido el matrimonio en oficio, pues viven de los regalos que los amantes hacen a sus esposas (p. 177). Las quejas de nuestro escritor sobre la decadencia de la sociedad en la que le ha tocado vivir no es nueva, sino que abunda entre los humanistas del siglo xvi; baste aquí citar, como ejemplo, las palabras de Adrian Turnèbe que calificaba el siglo xvi como una «detestable époque», abandonada por Dios y en la que triunfaba el vicio ${ }^{14}$, y cómo Le Roy en su Vicissitude añoraba los antiguos tiempos de una sociedad francesa fuertemente jerarquizada en la que «distinguans par les habits les princes des subjects, les magistrates des privez, les nobles des villains, les doctes des ignorants, les sacrez des prophanes ${ }^{15}$. Quevedo refleja esa misma visión pesimista que transmiten los humanistas franceses citados, pero con

12. España defendida, p. 172: “Mientras tuvo Roma a quien temer y enemigos, iqué diferentes costumbres tuvo! iCómo se ejercitó en las armas! iQué pechos tan valerosos ostentó al mundo! Mas luego que honraron sus deseos perezosos al otio bestial con nombre de paz santa, iqué vicio no se apoderó de ella!».

13. Sentimiento de añoranza que también manifestó Osuna en su famosa carta a Quevedo: «que pudiera Dios haberme hecho nacer cien años antes o guardado para estos tiempos los hombres que tuvo en aquellos, pero como no nos dio a escoger a los unos ni a los otros, no se puede hacer más de levantar el espíritu y darle gracias por todo. Prometo a Vuestra Merced que me miro hoy en el mundo por hombre embarazoso en él» (Sliwa, 2005, pp. 224-225).

14. Ver Jehasse, 1976 , p. 55.

15. Citado por Jehasse, 1976, p. 53. Recuérdese la queja similar de Cornelia en el coloquio erasmista de El pequeño senado o la asamblea de las mujeres: "Antaño un pañuelo colgando de la toca servía para distinguir a las mujeres de la aristocracia de las del pueblo. Después, para evitar toda confusión, las nobles comenzaron a llevar un penacho de 
una diferencia fundamental, que tiene que ver con su intencionalidad política, él sí ve una solución al problema, una solución personificada en Felipe III y sus ministros:

$\mathrm{Al}$ fin se ve en estado España, por nuestros pecados, que a no intervenir rey tan santo y tan justo y honesto, y ministros tan conformes a su virtud y tan celosos de su opinión y del servicio de Dios y del aumento del reino, deseperara a las vueltas del tiempo de poderla traer a peor estado (p. 177).

En la concepción del poder político de Quevedo es el rey el que gobierna y el que, por tanto, debe salvar al país del abismo moral en que se halla; esto se aprecia claramente en este párrafo y en otros momentos de la «laus» en que exalta al monarca como garante de la grandeza de España. Junto a él coloca a los ministros a los que, sin embargo, no personaliza, cosa rara pues en Discurso de las privanzas terminaba el texto con un encendido elogio a la figura del duque de Lerma, en palabras dirigidas a Felipe III:

Dé v.M. gracias a Dios de que le ha dado un criado tal como el Duque, que no le ha dado lugar que tenga nombre lo que le ha dado más de merced que de paga y premio. Tanto y tan bien ha servido y sirve, que merece bien que sean semejantes suyos los que le ayudan a llevar la carga que solo en sus hombros descansa (p. 249).

Este Discurso fue escrito en un momento en que se produce, quizás por interés del Duque, una campaña de promoción de su imagen y, como consecuencia de ella, una discusión teórica sobre el tema del valimiento, en la que destaca el Discurso del perfecto privado, de fray Pedro de Maldonado ${ }^{16}$. Sin embargo, en España defendida, escrita entre 1609 y 1612, el privado no aparece, Quevedo no le dedica ningún elogio ni crítica quizás porque, con motivo de la política pacifista, su codicia y la corrupción de varios de sus ministros, que empezaban a ser juzgados por la justicia (por ejemplo Franqueza, que fue sentenciado en septiembre de 1609 a cárcel de por vida y a devolver a la Real Hacienda un millón cuatrocientos mil ducados), lo que ha llevado a un historiador moderno a afirmar que durante su valimiento «la corrupción clavó sus garras en la administración pública ${ }^{17}$, podía haberse iniciado un cambio en la consideración en que Quevedo tenía al Duque ${ }^{18}$.

pieles blancas con manchas negras, que las del pueblo hicieron suyas inmediatamente» (2001, p. 287).

16. Ver Feros, 2002, pp. 215-220.

17. Pérez Bustamante, 1945, p. 161. Alvar, 2010, p. 19, califica la privanza de Lerma como una “cleptocracia»; Bennassar, 1983, p. 31, afirma que Lerma «había actuado exactamente como un jefe de una banda, como un maestro de la extorsión».

18. Sobre la relación y opiniones de Quevedo sobre el duque de Lerma hasta 1615 , ver Roncero, 2009 y 2013 a. 
España defendida constituye, pues, un texto interesante porque combina los intereses políticos con los humanistas de nuestro autor. Quevedo decidió escribir una «laus Hispaniae» ${ }^{19}$ para defender a España, como su propio título indica, de los ataques de los humanistas franceses y holandeses (Muret, Mercator, Scaliger), lo que ha llevado a algún historiador a considerar, creo que de forma errónea, la obra como «panfleto» nacionalista ${ }^{20}$. Se trata, por tanto, de un texto humanista porque aprovecha sus conocimientos de los autores clásicos y de los humanistas europeos del siglo xvi y los utiliza como un arma para derrotar a los enemigos franceses y holandeses de su patria, en esta ocasión no en los campos de batalla de Italia o de Holanda, sino en la arena de las ideas, de los conocimientos que abarcan desde Aristóteles hasta las poesías de Herrera o los textos históricos de Zurita o de Ambrosio de Morales, pasando por La Celestina o el Lazarillo de Tormes. Quiere entrar con este texto en el combate que se daba en Europa por la supremacía entre los grandes estados que se arrogaban la preeminencia basándose, no solo en las armas, sino también en las letras, siguiendo la tradición del tópico latino de la «sapientia et fortitudo».

Pero el texto quevediano no supone únicamente un monumento intelectual, sino que además contiene un importante mensaje político: Quevedo hace uso del tópico catoniano del «pugna pro patria» para demostrar su apoyo al rey Felipe III, al que ve, como ya hemos apreciado, como el salvador de España, como el continuador de una gloriosa monarquía de hombres virtuosos, como el restaurador de unas virtudes que habían convertido al pueblo español en el pueblo elegido, heredando esta posición del pueblo hebreo. Para ello va a utilizar todos los recursos de su arsenal humanista: las descripciones de Hispania de Estrabón y Pompeyo Trogo-Justino; la antigüedad del nombre de España, el protoespañol, lengua derivada del hebreo, la grandeza de los escritores, historiadores y científicos españoles de los siglos XV y XVI, la pureza de nuestras costumbres ancestrales que reflejan un país puro, contaminado por las plagas introducidas por las viciosas y corruptas naciones vecinas:

¿Quién no dice que somos locos, inorantes y soberbios, no teniendo nosotros vicios que no le debamos a su comunicación de ellos? ¿Supieran en España qué ley había para el que lascivo ofendía las leyes de la naturaleza, si Italia no se lo hubiera enseñado?, ¿hubiera el brindis repetido aumentado el gasto a las mesas castellanas, si los tudescos no lo hubieran traído? Y, al fin, nada nos pueden decir por oprobio, sino es lo que ellos tienen por honra, y averiguado, es en nosotros imitación suya. Ociosa hubiera estado

19. Sobre el concepto y desarrollo de la «laus Hispaniae» en España defendida, ver Roncero, 2013b, pp. 29-52.

20. Kamen, 2006, p. 271. Schmidt, 1976, p. 37, afirma sobre la laus quevediana que: «es obvio, que Quevedo oscila entre un nacionalismo narcisista y un nacionalismo misionero». 
la santa Inquisición si sus Melantones, Calvinos, Luteros y Zuinglios y Besas no hubieran atrevídose a nuestra fe (pp. 92-93).

El «protonacionalista» Quevedo atribuye la homosexualidad, el alcoholismo y las herejías a los italianos, alemanes, suizos, es decir, a los extranjeros que han pervertido la pureza católica de los españoles medievales. Este paisaje tan desolador de las miserias morales de sus compatriotas no desembocará en la ruina del Imperio porque el «santo» rey Felipe III reformará las costumbres y la monarquía recuperará aquella sobriedad y moralidad propia del pueblo elegido por Dios.

El carácter combativo del texto frente a los ataques y críticas de ciertos humanistas refleja de una manera implícita una defensa de una política agresiva hacia los estados enemigos de la Corona española. Es muy interesante observar cómo el autor destaca en varias ocasiones el carácter guerrero de los antiguos españoles, algo que ya aparece en filósofos como Platón y Aristóteles y que los humanistas italianos, por ejemplo, también reflejaban en sus escritos sobre España ${ }^{21}$. Quevedo redacta la obra en los momentos posteriores a la firma de la Tregua de los Doce Años, tratado que se encontró con la oposición de varios ministros y nobles, entre los que se encontraba el duque de Osuna, que «veían este proceso como una suerte de corrupción de la esencia católica de la monarquía hispana» (Feros, 2002, p. 346), del que se culpaba fundamentalmente a Lerma, como demuestran las palabras del secretario del embajador inglés Francis Cottington:

Vuestro tratado de paz es tan odiado aquí que muchos no se contienen de recriminar públicamente a Lerma (que se ha apoderado del gobierno), diciendo que, de no haber sido un ser vil y traidor, esas propuestas no habrían partido de un rey de España. Si tuviera que haceros entender la grandeza de este hombre, pensaríais que he escrito mentiras monstruosas ${ }^{22}$.

Un año antes de la firma del Tratado se había fraguado una alianza entre fray Luis de Aliaga, confesor del rey, y el duque de Uceda, hijo del duque de Lerma, para imponer «una posición más agresiva de la monarquía hispana en Europa» (Feros, 2002, p. 378). También don Baltasar de Zúñiga se lamentaba de la presunta debilidad del gobierno español

21. Basta como ejemplo la opinión de Guicciardini sobre los españoles: «Son inclinados a las armas -quizás más que ninguna otra nación cristiana-, siendo aptos para ellas porque son de estatura ágil y muy diestros y ligeros de brazos. En las armas estiman mucho el honor, de manera que para no mancharlo, no se preocupan para nada de la muerte» (1993, p. 238).

22. Citado por Allen, 2001, p. 289. Sin embargo, el historiador británico (p. 291) duda de la influencia de Lerma en los asuntos de Holanda, pues en esta época estaba enfermo y, por tanto, estuvo alejado de Felipe III durante gran parte de la primavera de ese año. 
en hacer frente a los asuntos europeos ${ }^{23}$. Quevedo, pues, entroncaría perfectamente con este pensamiento que se estaba extendiendo por la corte madrileña y, por ello, en su España defendida se posiciona al lado de estos descontentos y refleja el espíritu imperialista de su amigo y protector Osuna, defendiendo el «mantenimiento de un cierto nivel de actividad bélica, que equilibre los peligros de la paz prolongada» (López Ruiz, 2008, p. 60). En este sentido hemos de entender las palabras de Quevedo, cuando, después de haber advertido al monarca de lo que le sucedió al Imperio Romano, escribe refiriéndose a la España de su tiempo:

y así en esta poca paz que alcanzamos, en parte maliciosa, el largo hábito a las santas costumbres de la guerra la sustenta en ella, aunque a mi opinión España nunca goza de paz: solo descansa, como ahora, del peso de las armas, para tornar a ellas con mayor fuerza y nuevo aliento. Y son a todos como a ella importantes las armas suyas, pues, a no haberlas, corriera sin límites la soberbia de los turcos y la insolencia de los herejes, y gozaran en las Indias seguros los ídolos su adoración, de suerte que es orilla deste mar, cuya Gloria es la obediencia destas olas que solamente la tocan para deshacerse (p. 172).

Es interesante el uso del adjetivo «maliciosa» que creo hace referencia a la Tregua, puesto que se trataba de un hecho que traicionaba, como hemos visto, la defensa de la religión católica, por una parte, y por la otra, suponía una especie de claudicación frente a unos vasallos rebeldes. Además, como muy bien afirma Feros, esta tregua fue entendida en Europa «no solo como una declaración de derrota temporal, sino también como el inicio de una política de retirada total» (2002, p. 371). Para advertir a los enemigos y a los propios españoles, Quevedo defiende el hecho de que esta paz temporal sirve, o debe servir, en realidad, para prepararse mejor para las futuras contiendas en que, sin lugar a dudas, iba a verse inmersa la corona española en los años siguientes. Pero su razonamiento va más allá, cuando realza el fundamental papel de España en la contención de la amenaza turca, sobre todo, en el Mediterráneo, y en la defensa de la verdadera fe frente a los herejes europeos, añadiendo en este contexto religioso la alusión a la labor evangelizadora de los españoles en América ${ }^{24}$. De esta manera, nuestro escritor comunica a sus interlocutores europeos los estrechos lazos que unen a España con Dios, que ha protegido al Imperio, a sus reyes y a sus soldados en las constantes guerras en que se han visto envueltos, defendiendo y extendiendo su doctrina por aquellos lugares conquistados:

23. Feros, 2002, p. 394. El mismo historiador recuerda que Rivera, arzobispo de Valencia, se había opuesto a este tratado por la «razón de estado católica», puesto que suponía el abandono de la defensa del catolicismo frente a las necesidades seculares (pp. 352-353).

24. Sobre la imagen negativa de América relacionada con la codicia en la obra de Quevedo, especialmente en La Hora de todos, ver Roncero, 2010. 
Como Dios de los ejércitos, unas veces, nos amparó, y estas fueron muchas, con nuestro patrón Santiago; otras con la cruz que, hecha a vencer la misma muerte, sabe dar vida a todos los que, como estandarte de Dios, acaudilla. Milicia fuimos suya en Las Navas de Tolosa. La diestra de Dios venció en el Cid, y la misma tomó a Gama y a Pacheco y a Alburquerque por instrumento en las Indias Orientales para quitar la paz a los ídolos. ¿Quién sino Dios, cuya mano es miedo sobre todas las cosas, amparó a Cortés para que lograse dichosos atrevimientos, cuyo premio fue todo un Nuevo Mundo? Voz fue de Dios, la cual halla obediencia en todas las cosas, aquella con que Jiménez de Cisneros detuvo el día en la batalla de Orán, donde un cordón fue por todas las armas del mundo (pp. 174-175).

Quevedo hace una enumeración amplia de sucesos y personajes, tanto castellanos como portugueses, que han vencido a herejes desde la Edad Media (Navas de Tolosa, el Cid), hasta el siglo xvi (Cortés, Alburquerque, Cisneros). En todos los casos asocia al héroe con Dios o en un caso con el apóstol Santiago. Todas estas hazañas y victorias se deben a la intervención divina, es decir, la Divina Providencia ha ayudado a los españoles a derrotar a todos aquellos que se oponen al verdadero Dios, por lo que España ha de ser considerada como el pueblo de Dios, idea recogida por otros muchos autores, entre otros fray Juan de Salazar:

$\mathrm{Y}$ a mi ver, entre las (naciones y gentes) que han militado y militan debajo del suave yugo de la ley de gracia, a ninguna le cuadra más el nombre de pueblo de Dios que a la española, por proporcionarse con ella más que con otra alguna, muchas de las mayores promesas hechas al pueblo israelítico, a quien expresamente llama por sus profetas Esaías y Jeremías, pueblo y mayorazgo suyo (p. 73).

La «laus Hispaniae» quevediana, concebida como defensa contra los ataques de Scaliger, Muret y otros humanistas, se lee como un escrito político en el que el escritor madrileño aprovecha las armas de la erudición filológico humanista para entrar en el debate político que empezaba a producirse en el gobierno Felipe III-duque de Lerma entre aquellos que buscaban la paz como forma de restaurar la monarquía, con el riesgo de proyectar ante los enemigos (Francia, Inglaterra, Holanda) una imagen de debilidad y de retirada, y la de aquellos nobles y religiosos que abogaban por una política agresiva que tendría como objetivo el mantenimiento de los territorios conquistados por los monarcas anteriores y, además, serviría para algo tan importante como para conservar la reputación, concepto que será fundamental, sobre todo, en el principio del reinado de Felipe IV y sus (ministros» el conde-duque de Olivares y don Baltasar de Zúñiga. Quevedo le ofrece al monarca, al que dedica la obra, la visión de las dos Españas: la Castilla medieval (cuatrocientos o quinientos años anteriores a su reinado) en la que sus habitantes vivían una vida sobria y completamente dedicada a la virtud, a Dios y a la lucha contra los enemigos de la fe, fundamentalmente, los 
árabes que habían conquistado gran parte de la Península, con unos conceptos que preceden en unos quince años a la famosa «Epístola satírica y censoria contra las costumbres presentes de los castellanos», dedicada al conde-duque de Olivares; la España de principios del siglo xVII, una monarquía en paz, y que, como le sucedió a Roma, se halla sumergida en una espiral de depravación moral, en la que hombres y mujeres se confunden y en la que el vicio se apodera de la vida de sus habitantes que han olvidado las raíces y las virtudes que hicieron de España el pueblo elegido por Dios para reemplazar al «pueblo israelítico». La única salvación de esta monarquía se halla en las manos del rey que debe reconducir a la sociedad y devolverla a esa época gloriosa que hombres como Osuna y él mismo añoraron.

En 1613 Quevedo se embarca para Sicilia, llamado por su amigo el duque de Osuna, virrey de la isla. A partir de la llegada a este virreinato italiano, donde ya lo hallamos a finales de octubre, nuestro escritor inicia su trayectoria política como secretario y confidente del virrey, o como lo define Astrana Marín (1940, p. 12), su valido y persona de confianza, percepción que tuvieron sus contemporáneos, tal y como afirma Gasparo Spinelli, embajador o residente de Venecia en Nápoles: "perchè don Francesco de Chevedo, ch' è un prete che fa professione di mago, et ch' è tanto favorito dall'Eccellenza Sua che mai se le parte dal lato» (Crosby, 1958a, p. 12) y otros cronistas napolitanos de la época ${ }^{25}$. No voy a entrar a detallar los viajes que, en nombre de Osuna y del parlamento de Nápoles, hizo a Madrid entre ese año y el de su vuelta definitiva a España en 1619; para eso ya están los trabajos de reputados quevedistas que los han documentado con gran minuciosidad ${ }^{26}$. Son años en los que Quevedo se convierte en protagonista de la alta diplomacia: visita y se entrevista con el papa Paulo V, con el rey Felipe III, con Lerma, con Calderón, con Uceda; años en los que hace viajes en misiones secretas a Niza y a Venecia para defender los intereses de la Corona española y del Virrey; años en los que viaja a Madrid para traer donativos del parlamento Napolitano para el monarca y dinero de Osuna para «regalar» a los poderosos (Uceda, Calderón y Aliaga, entre otros) para que estos favorecieran los intereses del Virrey en la Corte, y que convirtieron a don Francisco en un personaje perseguido por los codiciosos miembros de la administración real ${ }^{27}$. Pero toda esta actividad se vio pronto frustrada, en unos momentos de luchas intestinas

25. Recuérdense las palabras del diarista napolitano Francesco Zazzera: «La sera a'mezzhora di noue s.e., sbrigato da quelli spossa, si e posto nel suo carrozzino da uno cavallo insieme con un gentilhuomo spagnolo fatto se venire per le poste da Spagna, col quale, havendo grandiss ${ }^{\mathrm{a}}$ simpatia, di rado si vede senza quello» (Crosby, 1958a, p. 13). Por supuesto, este "gentilhuomo» era don Francisco.

26. Ver Crosby, 1955a, 1955b, 1956, 1958a, 1958b, y López Ruiz, 2008, pp. 65-70.

27. En una carta a Osuna datada el 16 de diciembre de 1615 escribía Quevedo a Osuna: «Yo recibí la letra de los treinta mil ducados de once reales [...] Ándase detrás de mí media corte, y no hay hombre que no me haga mil ofrecimientos en el servicio de Vuestra Excelencia que aquí los hombres se han vuelto putas, que no las alcanza quien 
entre padre e hijo (Lerma y Uceda), apoyados e, incluso, manejados por otros miembros de la nobleza (Zúñiga y Olivares) que contendían por lograr el apoyo real a sus políticas opuestas, que arreciaron tras la caída del Cardenal-duque y que un historiador contemporáneo ha calificado de (guerra de guerrillas» (Feros, 2002, p. 439) ${ }^{28}$. Su aventura terminó de manera abrupta como una víctima más de esa lucha por el poder, con la acusación veneciana de la famosa “Conjuración», en la que no participó, pero que consiguió acabar no solo con su carrera política, sino también con la de su protector el duque de Osuna ${ }^{29}$.

La vuelta de Quevedo a España en 1619 debió suponer un duro golpe para Quevedo por lo que suponía de cierre de una etapa importante en su vida. Por otra parte, tras su llegada a Madrid y viaje a Lisboa, «quizás por encargo de Osuna» (Pérez Bustamante, 1945, p. 182), fue desterrado a La Torre de Juan Abad antes de iniciarse el proceso, después fue recluido en Uclés, como caballero de la orden de Santiago y vuelto a la Torre hasta que fue llamado a Madrid para prestar declaración en el proceso que se incoó a Osuna y sus colaboradores. En este intervalo de tiempo, y durante su estancia en su Torre decidió narrar los últimos años del reinado de Felipe III y los primeros de su sucesor, Felipe IV, en un texto al que puso el sugestivo título de Grandes anales de quince días. Historia de muchos siglos que pasaron en un mes. Memorias que guarda a los que vendrán don Francisco de Quevedo y Villegas. La dedicatoria del texto está fechada el 16 de mayo de 1621, que corresponde al momento en que inició su escritura, pues los acontecimientos narrados se inician con la referencia a la muerte de Felipe III el 31 de marzo de 1621 y llegan hasta el 10 de marzo de 1623, fecha en la que «hizo su majestad merced al secretario Pedro de Contreras de los papeles y consultas que tenía Antonio de Arostigui, con retención de sus oficios, y que tuviese a su cargo el bolsillo» ${ }^{30}$. Los límites cronológicos, sin embargo, no se corresponden con estas fechas, por lo que se refiere a sus inicios, pues aparecen recogidos sucesos que acaecieron en 1618, como veremos a continuación. La obra tuvo un gran éxito entre los lectores de los siglos XVII y XVIII pues conservamos más de cuarenta manuscritos de las tres redacciones del texto ${ }^{31}$.

Nos encontramos, sin duda, ante un texto muy interesante, pues el escritor narra acontecimientos de los que fue testigo y partícipe, y otros de los que debió recibir información de primera mano, pues, como hemos visto, Quevedo se hallaba desterrado en La Torre o prisionero en

no da [...] adelante ha de haber tiempo de untar estos carros para que no rechinen; que ahora están más untados que unas brujas» (Sliwa, 2005, p. 189).

28. Ver también García Cárcel, 2003, p. 292.

29. Sobre este tema ver Crosby 1955b. López Ruiz, 2008, pp. 68-69, afirma que el episodio narrado por Tarsia de la huida de Quevedo disfrazado de mendigo de Venecia sí es auténtico, pero que este acaeció en mayo-junio de 1617, es decir, un año antes de la pretendida Conjuración.

30. Noticias de Madrid, p. 49.

31. Sobre la cuestión ecdótica ver Roncero, 1994 y 2005. 
Uclés cuando sucedieron algunos de los sucesos narrados en la obra ${ }^{32}$. Sin embargo Quevedo hace gala en el prólogo de su presencia en los episodios históricos que narra: «Yo escribo lo que vi, y doy a leer mis ojos, no mis oídos. Con intención desinteresada y con ánimo libre me hallé presente a lo que escribo con más recato que ambición» (p. 59).

En estas palabras nuestro escritor suscribe dos principios de gran tradición en la historiografía clásica: ser testigo de los hechos narrados; la imparcialidad. El primero de ellos tiene su primera referencia en la obra de uno de los padres de la historia: Tucídides. El historiador griego afirma que

En cuanto a los hechos de lo que sucedió en la guerra, no consideré adecuado escribirlos informándome del primero con quien me topase ni según me parecía, sino solo aquellos en los que estuve presente o, yendo a buscarlos a otras fuentes con cuanta exactitud era posible en cada caso ( $\mathrm{I}$, 22 , pp. 65-66).

Quevedo, como perfecto conocedor tanto de la historiografía clásica, como de la humanista, reconocía la importancia de la presencia del historiador como testigo de los hechos narrados, para de esa forma, al menos teóricamente, relatarlos con una mayor fidelidad a la verdad histórica, aunque como matizan algunos historiógrafos: «las historias están por cuenta y a cargo de los príncipes»»33. Por lo tanto, Quevedo quiere dejar claro desde un principio su calidad de testigo de la mayor parte de los acontecimientos que describe en Grandes anales lo que proporcionaría a su discurso un prurito de exactitud histórica por lo que utiliza el yo «validando, dando autoridad a su discurso desde su pretendida posición de conocimiento y cercanía a la corte y en su calidad de testigo de vista, incluso de protagonista directo» ${ }^{34}$. Quevedo pretende atribuirse una proximidad a los hechos de la que carecen algunos de sus contemporáneos, proximidad que llevaría aparejada la imparcialidad, algo que ha sido puesto en duda por alguna quevedista actual ${ }^{35}$. Quevedo recuerda aquí el sine ira et studio de Tácito, que se convirtió en maxima de los historiadores posteriores al autor de los Anales. El valor que nuestro escritor quiere dar a su historia se basa en el concepto de que está relatando una crónica histórica sin ningún tipo de parcialidad, debida a sus propios intereses o a las presiones recibidas desde el poder. Don Francisco reconoce que su obra solo tiene valor, por lo menos valor histórico, si está libre de cualquier otro interés que el de reflejar la

32. Elliott, 1991, p. 23, considera Grandes anales como: «una brillante muestra de la narración a distancia». Sobre la relación entre historia y literatura en esta obra ver Roncero, 1993.

33. Cabrera de Córdoba, De historia, p. 31.

34. Peraita, 1997, p. 189.

35. Juárez, 1990, p. 178, acusa al autor de falta de objetividad y de perspectiva histórica. 
verdad de unos sucesos que, en su opinión, podían suponer una nueva época en la historia de España.

¿Podemos creer a don Francisco en su afirmación de ser testigo imparcial de los hechos narrados? Desde luego, como han puesto de relieve algunos estudiosos de los Grandes anales, existe por parte del autor un interés personal claro: «conectar con los Guzmán, forjar una relación de patronazgo, de resucitar su descalabrada carrera política» (Peraita, 1997 , p. 110) ${ }^{36}$. Si recurrimos a la biografía de Quevedo veremos que en el momento de empezar la escritura de la obra se hallaba en su destierro manchego, alejado de la corte, y que su protector y amigo, el duque de Osuna, no solo había caído en desgracia, sino que había sido arrestado el 7 de abril. Por todo ello, Quevedo debía presentar sus credenciales de inocencia y de lealtad al nuevo monarca y a sus privados con la esperanza de recibir el perdón y quizás recuperar algo de su prestigio político ante los nuevos gobernantes. La mejor forma de lograr estos objetivos sería la redacción de estos Anales en los que combina su grito de inocencia con el halago a Felipe IV y a don Baltasar de Zúñiga y Olivares a los que presenta como el principio de una nueva España, pero sin cargar las tintas contra el régimen anterior, en cuya política, al menos en Italia, había jugado un papel importante; así hemos de entender la siguiente afirmación hecha en el prólogo «Al que leyere»:

Ni pondero ni disimulo las acciones; y porque pretendo informar los oídos, no regalarlos ni ofenderlos, dejo a las malicias de mi silencio remitidas las conjeturas del estado que tuvo España cuando la muerte, con advertencia lastimosa, hizo fábrica de tan grandes ruinas (pp. 59-60).

Estas afirmaciones distan mucho de los juicios expresados por algunos de los «propagandistas oficiales» del valido Olivares que presentan una imagen ruinosa de la España que dejó al morir Felipe III, como la que describe Malvezzi, para quien

La benignidad de Felipe III y la insaciabilidad de los ministros habían reducido cadáver el cuerpo de esta monarquía, el alma de quien es el oro y el consumir los erarios, si no es el más malo de los vicios, es el más dañoso [...] Esta nao de la monarquía de España también por falta de pilotos amenaza naufragios; y quizá estaba en lo hondo de la mar y no se ahogaba porque su grandeza sobrepujaba la vastedad de las aguas ${ }^{37}$.

Por supuesto, que también existen los cronistas que opinan lo contrario: el gobierno de Felipe III fue una época gloriosa y el de su hijo de

36. Huarte, 1945 , p. 182, comenta que un posible motivo de inspiración de la obra es congraciarse con Olivares.

37. Malvezzi, Historia, p. 3. Céspedes y Meneses, fol. 1v., habla de que la política pacifista y monetaria de Felipe III y sus validos camagaban seguros males a su imperio, y que era lícito argüir del nuevo príncipe español que había venido a ser reparo o a ser testigo de su ruina». 
“miseria y calamidad», en palabras de Matías de Novoa ${ }^{38}$. Pero Quevedo no debía destruir totalmente el recuerdo del reinado de Felipe III, porque eso podía debilitar su proclamada imparcialidad, y porque él en un momento se había identificado y había participado en la política internacional desarrollada por Lerma y Uceda-Aliaga. Pero es que, además, uno de los conceptos básicos de su teoría política alertaba sobre la imposibilidad para los vasallos de juzgar al monarca y sus decisiones, tal y como afirma en Grandes anales:

Dignos son de todo castigo aquellos que con ánimo sacrílego se atreven a juzgar a los reyes, pues no pueden alcanzar la disculpa de sus acusaciones los que no lo hubieren sido y tuvieren experiencia de los encantamientos de la adulación, de los divertimientos inevitables de la maña, y de la prisión que a un monarca fabrican los ambiciosos (p. 104).

Don Francisco disculpa al rey por los errores que hubiera podido cometer, que fueron debidos, por otra parte, a aquellos ministros y cortesanos “ambiciosos» que distorsionaron su visión de la realidad y le llevaron a cometer errores. No olvidemos que nuestro escritor defendía el origen divino de la monarquía y por eso emplea el adjetivo «sacrílego» para calificar a quienes «se atreven a juzgar a los reyes». Desde este punto de vista político-teológico se explica que el adjetivo que se emplea para definir a Felipe III sea el relacionado con la santidad, rasgo que mencionaron otros autores de la época ${ }^{39}$ y que ya destaca en el primer párrafo de la obra: «A 31 de marzo de este año de 1621, a las nueve de la mañana, la majestad del rey don Felipe III pasó a mejor vida, que en los justos y santos tiene más corteses y más consolados nombres la muerte» (p. 60). En otros momentos habla de la "santidad inculpable del difunto» (p. 61), se refiere a él como «santo rey» (p. 62), y en un texto muy interesante comenta:

Quién, acordándose de su santidad, llamaba a los sucesos en la conservación de su monarquía milagro continuado, atribuyendo, no sin causa, los aciertos a sus méritos y los descuidos (si los hubo) a algunos ministros de quien fio más de lo que convenía, si menos de lo que supieron desear los que sin entenderlo no conocieron el peligro en la obligación, divertidos con los juguetes del poder prestado que a su atención adormecida pasaba las asechanzas por aplauso (p. 65).

Aquí apreciamos perfectamente la concepción de la monarquía que postulaba Quevedo, en este caso, adaptándola a la figura de Felipe III

38. El partidario de Lerma afirma: «y que veamos por secretos juicios la miseria y calamidad de los tiempos presentes, en que Dios, por todo lo referido, ha querido volver por los pasados, suspirando y trayendo a la memoria los vasallos aquellos en que fueron gobernados por la libertad y clemencia del Rey don Felipe III» (Novoa, LXI, p. 468).

39. Almansa, 2001, p. 169: “Hízole hacer muchos actos de contrición, repitiendo el santo rey, como si fuera un niño, cuanto le decía» 
el «santo», que conservó sus territorios y poder gracias a los milagros, no a sus ministros que solo se preocupaban de la conservación de su poder y de sus propias ambiciones dejando de lado el bien de la república. Se trata de un argumento que repetirá en muchas ocasiones por el que reserva la responsabilidad de los males y fallos del gobierno a los nobles y funcionarios de la administración real, mientras que atribuye los aciertos al monarca.

Pero Quevedo no puede rechazar su actividad política durante los años 1613 a 1619 a las órdenes del duque de Osuna, que es perseguido por el nuevo equipo de gobierno como una forma más por parte de Olivares y Zúñiga de desvincularse de los errores y de la corrupción de Lerma y sus ministros. Por eso nuestro escritor trata de lavar su imagen en los casos que la justicia presenta contra el noble y contra él mismo; está en juego su propio futuro político. Su principal misión será la de reivindicar la legalidad, tanto en las actuaciones de su protector como en las suyas propias. Le preocupa, sobre todo, la reputación, por lo que su primer comentario sobre el encarcelamiento de Osuna es el de considerarlo como

que a mi ver fue conveniente a la reputación del Duque; y creo necesitaba de tales demostraciones de persecución porfiada de los napolitanos; y que no tenía más eficaz remedio la opinión del Duque, tan ajada de amigos y enemigos, pues por este camino podrá ser la justicia le absuelva de lo que sin nota grande no pudiera desentenderse la gracia (p. 69).

Osuna había jugado un papel importante en Italia y a su vuelta a Madrid «era uno de los personajes con mayor experiencia política y militar en la Corte» (Linde, 2005, p. 240). Todavía antes de la muerte del «santo» monarca ejercía una gran influencia en la Corte, como lo demuestran las palabras del propio Quevedo, atribuyéndole un papel protagonista en el intento de forzar la vuelta de Lerma a la Corte con el rey moribundo ${ }^{40}$. Pero la muerte de Felipe III y la subida al poder de Felipe IV con sus dos privados supuso un vuelco en su suerte y su arresto lo convirtió, como comenta Vera y Figueroa, en «la primera persona en quien se ejecutó el golpe del nuevo gobierno» (p. 166). Quevedo se vio arrastrado por esta caída y su intento con la narración de las desgra-

40. Uceda, narra Quevedo en Grandes anales, pp. 62-63, «luego que se vio excluido de la gracia, se arrojó a valerse de la determinación perezosa; escribió al Cardenal se viniese a toda diligencia. Valióse para esto de la resolución del duque de Osuna a tiempo que el consejo fue delito, la diligencia burlada y la asistencia peligrosa. Y tuviera efecto la venida, si su majestad que hoy reina no se hiciera ejecutor de la voluntad de su padre, cosa que con una acción le mostró próvido, resuelto y obediente; con lo cual el Duque cardenal padeció el ímpetu de los buenos deseos mal ordenados, y el duque de Osuna los desabrimientos de fineza menos bien advertida que arrojada, y el duque de Uceda penitencia de pereza tan confiada y de confianza tan desentendida de otro tiempo y de otra fortuna». Sobre la caída de Osuna, ver Linde, 2005, pp. 212-258. Sobre el Duque y sus campañas navales, ver Fernández Duro, 2006. 
cias de su protector tiene que ver con su declaración de inocencia. Don Francisco defiende el gobierno del Duque y sus aciertos en la política militar frente a Venecia, Saboya y los turcos que había llevado a cabo, sobre todo, durante su cargo como virrey de Nápoles, valoración positiva compartida por los partidarios del anterior gobierno, como ponen de manifiesto las palabras de Novoa (LX) escritas a mediados del siglo XVII, cuando afirma que don Pedro Girón gobernó

con singular prudencia y grandeza de ánimo, que hoy confiesan, aunque no quisieron entonces, los más envidiosos (p. 401).

(Era) el terror en aquellos tiempos de los mares Mediterráneo y Adriático (p. 463).

Cuidadoso y alentado ministro (p. 465).

También Céspedes y Meneses lo presenta como buen gobernante y militar, encareciendo la restitución al reino de su cantiguo crédito; que reformando las costumbres hizo horrendísimos castigos y dio [...] a España triunfos y vitorias, y alguna tal, que, por notable, la llama el mundo prodigiosa” (fol. 37r).

Quevedo demuestra su fidelidad defendiendo al Duque, narrando la íntima relación que mantuvieron a la vuelta del virrey a Madrid y cómo eso pudo tener efectos negativos en su propia suerte. Su referencia a las acusaciones contra Osuna son vagas y se limitan a aludir a que el mayor cargo que se le hacía al «Duque era haber consentido de un Genuino, letrado napolitano (a quien había hecho electo del pueblo en lugar de Grimaldo), algunas lisonjas atrevidas, y que no le había castigado» (pp. 69-70). Lo mismo viene a afirmar Novoa, para quien los cargos contra Osuna eran mínimos, «de corregidor» (LXI, p. 312). Sin embargo, sabemos que había otras acusaciones que enumera, por ejemplo, Malvezzi, propagandista de Olivares, con mayor detalle y que eran más graves que las que cita nuestro escritor ${ }^{41}$. Quevedo termina la prisión del Duque refiriendo cómo este no presentó defensa frente a estas acusaciones pues tenía la conciencia tranquila. Esta alusión a la indiferencia del noble ante los cargos que se le imputaban la explica Malvezzi con una afirmación que recuerda la del propio Osuna sobre su nacimiento en una época equivocada: «Fue su desventura que mudaron los tiempos, su ruina que no supo mudar con el tiempo» (p. 34).

41. Malvezzi, Historia, p. 33: «de haber corrompido a los ministros principales con el dinero, alborotado en Nápoles el pueblo contra la nobleza, administrado mal la justicia con salvar a los reos y condenar a los inocentes, dejado de obedecer a las órdenes del rey, usurpado sus rentas, acumulado dinero con modos ilícitos, crecido el sueldo a los soldados, y, después de las cuentas hechas con Su Majestad, de haberlo pagado lo que quedaba deudor con naos armadas y otras cosas». Sin embargo lo disculpa del más grave: «No hubo cosa de infidelidad, ni tampoco de humo, no habiendo él en esta parte faltado ni a su sangre ni a su nación» (p. 33). 
Lo importante de este episodio es que Quevedo se convierte en protagonista del discurso histórico, pues se vio afectado por las investigaciones y acusaciones que se llevaron a cabo. Nuestro escritor decide introducirlo para recordar a Olivares y a Felipe IV su inocencia, porque les recuerda:

Llamome la junta del Duque con una carta, y vine de la Torre, donde estuve en mi casa por cárcel. Tomóseme mi declaración de las cartas que se hallaron mías, y después de haberla hecho, dieron sus cargos a todos, y a mí solo no me le hicieron, dándome por libre. De suerte que en mis cartas ni se vio necedad, ni se acusó delito. No lo digo esto por alabanza, sino por respuesta y relación forzosa. Ni yo sé que sea modestia levantarme testimonios, ni callar lo que me defiende la honra y la opinión, que si bien es estragada y perseguida, no infamada con nota de mala voz (p. 82).

Don Francisco señala los antecedentes de esta situación: prisionero en su casa de La Torre de Juan Abad se traslada a Madrid (marzo de 1621), le toman declaración (entre el 13 de agosto y el 6 de septiembre de 1621) y deciden dejarlo libre ante la ausencia de pruebas en su contra. Pero en su narración, el escritor se refiere a hechos anteriores, como su traslado desde La Torre a Uclés, por orden de Felipe III, por ser caballero de la orden de Santiago ${ }^{42}$, acontecimiento que sucedió entre finales de 1620 y principios de 1621. Retrocede más todavía cuando narra y transcribe sus conversaciones con el duque de Uceda y con don Rodrigo Calderón. Estos dos discursos muestran a un político experimentado que sabe leer los cambios de la fortuna política, pues aconseja a Uceda que se desligue de Osuna, acción que favorecería el futuro de ambos nobles:

Yo hablo ahora para otro tiempo, y fiscal de la buena dicha, hablo a propósito de la seguridad, si no del divertimiento. Vuecelencia desconfíe al Duque de su amparo para que no pueda culpar en vuecelencia la disimulación, ni en sí la confianza. Heme determinado a desabrirle porque quiero más enojarle que ofenderle, y quiero que antes se queje de mi sequedad que de mi entereza. No pido a vuecelencia licencia, sino abrigo; pues si me honra acompañándome en este propio intento, lograré mi diligencia; si no yo estoy resuelto a aventurar la gracia del Duque, y no su reputación ni la mía (p. 81).

El político-historiador se presenta como un leal consejero del duque de Osuna que, incluso, se atreve a «desabrir» al valido de Felipe III, cuando piensa que esa relación puede causar problemas a ambos duques, y dañar la reputación de su señor. A continuación narra su vuelta a Nápoles (finales de 1618 o principios de 1619), el recibimiento del Duque y su vuelta a España después del 6 de abril de 1619. Pero

42. La noticia también la recoge Almansa, 2001, p. 200: “A don Francisco de Quevedo y Villegas llevaron preso al convento de Uclés, como caballero de Santiago». 
Quevedo no quiere dejar la narración con el distanciamiento entre él y el Virrey, por lo que describe «las demostraciones de amor» (p. 82) que tuvo Osuna con él cuando se produjo el encuentro entre ambos en Madrid. El don Francisco político, que se ha forjado en estos años en la Península itálica con misiones diplomáticas (Paulo V, Felipe III, Uceda, Calderón), con misiones secretas a Niza o a Venecia, y con viajes a España en servicio oficial como representante del Virrey y del parlamento napolitano, ha aprendido a reconocer los avatares del poder y es por ello que se arriesga a enemistarse con el valido para salvar la reputación de su señor, que acaba reconociendo que su secretario estaba en lo cierto, cuando en Madrid, a vistas de todo el mundo le hizo «demostraciones de amor» (p. 82) y «decía que sólo yo le había dicho lo que si hubiera hecho, no se viera en el estado en que se hallaba» (p. 82).

Pero nuestro escritor se muestra cauto al describir su relación con Osuna y las consecuencias que esta tuvo; en este caso el Quevedo político se limita a narrar los sucesos sin dar demasiados detalles para evitar, suponemos, posibles represalias de Olivares que quería dar un castigo ejemplar a los principales hombres del régimen anterior: así vemos, que pasa casi como sobre ascuas sobre la cárcel y posterior destierro de $\mathrm{Uceda}^{43}$, aunque comenta un poco más ampliamente la prisión de Bonal y Tapia, consejeros del Supremo de Castilla:

O tuviese parte la advertencia de su majestad que está en el cielo, por alivio de su conciencia, o ya su majestad, cuidadoso de su república, quisiese empezar escarmentando, retiró a su casa dos consejeros del Supremo de Castilla, Pedro de Tapia y Antonio Bonal. Creo que la más poderosa parte de su deslucimiento fue estar notados de los odios comunes, y cantados con alguna nota en coplas que se van introduciendo en sentencias anticipadas (p. 66).

Como da a entender Quevedo, estos dos consejeros no eran los más corruptos de la anterior administración, sino que, como afirma Elliott (1991, p. 66), ambos «fueron obligados a jubilarse, no tanto por su gran venalidad, sino más bien como una señal de cuáles eran las intenciones del nuevo rey». Quevedo atribuye esta acción real a un aviso para otros funcionarios, pero también a los rumores que circulaban por la Corte, que habían sido recogidos en coplas satíricas por poetas como el conde de Villamediana ${ }^{44}$ y que se habían convertido en sentencia de culpabilidad anticipada contra estos dos consejeros.

43. «Al duque de Uceda, desacompañado ya del puesto que tuvo y de la soberanía, su majestad le despenó de andar por Madrid hecho escarmiento y desengaño; mandole (por orden que Villegas, gobernador del obispado, llevó a Acevedo, presidente) de que se retirase a su casa y a su lugar» (pp. 82-83).

44. Entre ellas el poema que comienza «Murió Felipe III»: «Anímese don Bonal / y a sí mismo se consuele, / porque a ninguno le duele / el verle en desdicha tal. / Lamente Tapia su mal, / pues tuvo bienes baratos; / conozca sus falsos tratados / mientras -cual dicen- descansa, / porque el diablo ya se cansa / de romper tantos zapatos» (Poesía impresa completa, p. 984). 
El episodio que más interés despertó en don Francisco y en los españoles de 1621 fue el de don Rodrigo Calderón, perfecto ejemplo del individuo que subió «de su principio humilde, corrió el cielo de la mayor privanza y de la mayor riqueza y al fin vino a parar a su principio» (Almansa, 2001, p. 213). Quevedo utiliza este suceso que impactó profundamente en la sociedad española de su tiempo con una intencionalidad claramente didáctico moralizante en la línea, por ejemplo, del Doctrinal de privados del marqués de Santillana en la que se presenta el caso de don Álvaro de Luna, que contiene muchas concomitancias con el de Calderón. Nuestro escritor relata la vida del marqués de Siete Iglesias desde los principios relativamente humildes del personaje para introducirlo como un arribista que se atrevió a llegar a lo más alto ${ }^{45}$. Don Rodrigo a partir de septiembre de 1598 fungió como «una suerte de consejero privado, cuando no de favorito, del valido» (Feros, 2002, p. 242) y despertó muchas antipatías entre los nobles y muchos individuos de la administración que ya en 1607 lo acusaron de corrupción, junto a Franqueza y Ramírez de Prado; estos dos últimos fueron arrestados por Felipe III y Lerma, pero Calderón fue exonerado y recibió la protección real, aunque su situación se resintión ${ }^{46}$.

Como en el caso de Uceda, Quevedo relata el encuentro que mantuvo con el privado de Lerma durante su estancia en Madrid en 1618, muy distinto al que se dio en 1615 entre ambos personajes ${ }^{47}$, en el que se comenta una carta que don Francisco le había enviado a Osuna aconsejándole que se correspondiese con el marqués de Siete Iglesias, carta que el Virrey envió a Calderón, lo que pudo haber puesto en un gran aprieto a nuestro historiador, y que este reconoció haber escrito, aliviado porque «fue arrojamiento venturoso por alcanzarle en tiempo que sus iras para la venganza tenían ya muy a trasmano el poder» (p. 80). Quevedo se enorgullece nuevamente de su actuación política que mira sobre todo a velar por los intereses de su señor sin considerar las posibles consecuencias negativas que podía haberle acarreado su actuación.

Quevedo relata su apresamiento en Valladolid el 20 de noviembre de 1619 y describe algunos de los cargos que se le hicieron: asesinato de la reina mediante envenenamiento, que don Francisco desacredita como «delirios» (p. 91), también los asesinatos de Avililla, de dos matones y de Francisco de Juara, asesinatos sin importancia y no merecedores de castigo, según Novoa $^{48}$. 2009.

45. Una magnífica biografía del marqués de Siete Iglesias es la de Martínez Hernández,

46. Martínez Hernández, 2009, p. 117, afirma que a raíz de estas acusaciones «la imagen pública de don Rodrigo quedó muy maltrecha. Su debilidad quedó expuesta».

47. Carta de Quevedo a Osuna fechada el 16 de diciembre de 1615: «El marqués de Siete Iglesias no solo me dio audiencia, pero me enseñó toda su casa, haciéndome mil favores (es apasionadísimo amigo de Vuestra Excelencia y muy seguro y se holgará para su camarín con algunas cosillas de Levante» (Sliwa, 2005, p. 189).

48. Novoa, LXI, p. 135: «Penétralo don Rodrigo, y no lo asombra, porque de lo que ha pecado sabe que no por una, sino por dos y aun tres muertes hechas en ruines hombres 
Nuestro escritor presenta como castigo justo el impuesto a don Rodrigo por el que Olivares y Zúñiga, y, por supuesto, Felipe IV, pretendían hacer un «juicio sumarísimo al valimiento de los Sandoval» (Martínez Hernández, 2009, p. 264). La relación de los hechos de Calderón da un giro importante cuando se le condena a muerte, concretamente el 9 de septiembre de 1621; algo que señala el propio Quevedo avisando al lector: «Oíd la historia de dos hombres y atended la historia del privado que nació de su ruina: veréis uno que se edifica con su caída» (p. 96). A partir de aquí se cambia el tono y de la descripción de su soberbia y de sus posibles delitos pasa a presentarnos a un hombre humilde que reconoce sus errores y que acepta con resignación cristiana la sentencia impuesta por el tribunal real; así podemos explicar la inclusión de la conversación que mantuvo don Rodrigo con fray Pedro de la Concepción, carmelita descalzo, en la que con gran humildad el ministro de Lerma termina por entregarse a los demás que intenten seguir sus pasos como ejemplo a contrario:

Dos cosas pido a Dios: que yo me sepa aprovechar de mis trabajos, y que los que me sucedieren en las veredas de la privanza me sean deudores del recato y acertamiento; que yo vi la sangre de otros, y en lugar de apartarme, resbalé en ella (p. 98).

Con la biografía y la narración de la azarosa vida de Calderón, Quevedo ha cubierto dos conceptos fundamentales en dos disciplinas muy próximas: la política y la historia. Por una parte, aconseja a los privados que han de ser conscientes de su estatus y no dejar llevarse por la soberbia y la ambición de poder, pues, como le ha sucedido a don Rodrigo y le sucedió a don Álvaro de Luna, el ministro que quiere volar muy alto acaba estrellándose. Por otra parte, tenemos el concepto historiográfico de la Historia como «magistra vitae», acuñado por los clásicos y que, como hemos podido ver, nuestro escritor recoge en su discurso histórico.

De esta manera, Quevedo combina en Grandes anales de quince días sus conocimientos de la historiografía clásica y su interés por participar en la vida pública, algo que pudo desarrollar plenamente en los años 1613 a 1619. Creo haber demostrado que don Francisco se entregó a estas dos facetas siguiendo la senda marcada por los humanistas florentinos del siglo $\mathrm{xv}$, que entendieron que eran perfectamente compatibles el ejercicio de la literatura o de la historia con el desempeño de un cargo público. Al fin y al cabo, la Historia, tal y como la entendían los clásicos, debía ser considerada como una herramienta fundamental para todos aquellos que pretendieran gobernar los estados modernos, pues de las decisiones acertadas y de los errores de nuestros antepasados se podían extraer las lecciones que ayudarían a nuestros gobernantes

por personas de poca importancia, se libran y pasean en la corte, cuanto y más un hombre de sus partes y de sus obligaciones»). 
hacia un mejor gobierno. Quevedo desde los primeros momentos de su madurez, las dos primeras décadas del siglo XVII, fue capaz de combinar ambas facetas y recoger sus experiencias, tanto la intelectual, como la práctica en varias de sus obras para transmitir a sus contemporáneos y a los españoles de siglos posteriores su concepción historiográfica y el retrato de una época convulsa desde la perspectiva de un individuo que contribuyó a diseñar una parte de la política italiana del Imperio español. Desgraciadamente para él el cambio de equipo de gobierno no le permitió continuar con esa actividad pública, pero quiso dejar constancia de que cuando se dedicó a ella lo hizo con entereza y lealtad a Osuna y al rey de España.

\section{BibLIOGRAFÍA}

Allen, Paul C., Felipe III y la (pax hispanica» 1598-1621. El fracaso de la gran estrategia, trad. José Luis Gil Aristu, Madrid, Alianza, 2001.

Almansa y Mendoza, Andrés de, Obra periodística, ed. Henry Ettinghausen y Manuel Borrego, Madrid, Castalia, 2001.

Alonso Veloso, María José, «Prólogo», en Francisco de Quevedo, Primera parte de la vida de Marco Bruto, en Obras completas en prosa. Tratados políticos, dir. Alfonso Rey, Madrid, Castalia, 2012, vol. v, pp. 643-689.

Alvar Ezquerra, Alfredo, El Duque de Lerma. Corrupción y desmoralización en la España del siglo XVII, Madrid, La esfera de los libros, 2010.

Aranguren, José Luis, «Lectura política de Quevedo», Revista de Estudios Políticos, XXIX, 1950, pp. 157-167.

Astrana Marín, Luis, Ideario de don Francisco de Quevedo, Madrid, Biblioteca Nueva, 1940.

Baum, Doris L., Traditionalism in the Works of Francisco de Quevedo y Villegas, Chapel Hill, University of North Carolina, 1970.

Bennassar, Bartolomé, La España del Siglo de Oro, trad. Pablo Bordonava, Barcelona, Crítica, 1983.

Cabrera de Córdoba, Luis, De Historia. Para entenderla y escribirla, ed. Santiago Montero Díaz, Madrid, Instituto de Estudios Políticos, 1948.

Céspedes y Meneses, Gonzalo de, Historia de don Felipe IIII. Rey de las Españas, Barcelona, Sebastián de Cormellas, 1634.

Cochrane, Eric, Historians and Historiography in the Italian Renaissance, Chicago, The University of Chicago Press, 1985.

Crosby, James O., "A Little-Noticed Parecer by Francisco de Quevedo», Modern Language Notes, LXx, 7, November, 1955a, pp. 518-521.

Crosby, James O., "Quevedo's Alleged Participation in the Conspiracy of Venice», Hispanic Review, xıII, 1955b, pp. 259-273.

Crosby, James O., "Quevedo and the Court of Philip III: Neglected Satirical Letters and New Biographical Data», Publications of the Modern Language Association, LXXI, 5, December, 1956, pp. 1117-1126.

Crosby, James O., «Noticias y documentos de Quevedo, 1616-1617», Hispanófila, 4, 1958a (la separata tiene numeración propia).

Crosby, James O., “Nuevos documentos para la biografía de Quevedo 16171621 », Boletín de la Biblioteca Menéndez Pelayo, xxxIv, 3, 1958b, pp. 229-261.

Díaz Martínez, Eva María, «Estudio preliminar», en Francisco de Quevedo, Discurso de las privanzas, Pamplona, Eunsa, 2000, pp. 13-194. 
Elliott, John H., El conde-duque de Olivares, trad. Teófilo Lozoya, Barcelona, Crítica, $1991^{6}$.

Erasmo de Rotterdam, El pequeño senado o la asamblea de las mujeres, en Coloquios, ed. Pedro R. Santidrián, Madrid, Espasa-Calpe, 2001.

Ettinghausen, Henry, «Quevedo, ¿un caso de doble personalidad?», Academia Literaria Renacentista. II. Homenaje a Quevedo, Salamanca, Universidad de Salamanca, 1982, pp. 27-44.

Ettinghausen, Henry, Quevedo neoestoico, Pamplona, Eunsa, 2009.

Fernández Duro, Cesáreo, El gran duque de Osuna y su marina, Sevilla, Renacimiento, 2006.

Feros, Antonio, El duque de Lerma. Realeza y privanza en la España de Felipe III, Madrid, Marcial Pons, 2002.

García Cárcel, Ricardo, “Reinado de Felipe III» en Historia de España, siglos XVI y XVII. La España de los Austrias, coord. Ricardo García Cárcel, Madrid, Cátedra, 2003, pp. 235-297

González de Amezúa y Mayo, Agustín, Las almas de Quevedo. Discurso leído en la RAE el 17 de febrero de 1946 para conmemorar el III Centenario de la muerte de don Francisco de Quevedo y Villegas, Madrid, Imprenta de S. Aguirre, 1946.

Guicciardini, Francesco, “Escritos autobiográficos. Relación de España», en Lorenzo Valla, et alii, Humanismo y Renacimiento, selección de Pedro R. Santidrián, Madrid, Alianza, 1993, pp. 235-256.

Huarte, Amalio, “Obervaciones a los Grandes anales de quince días», Revista de Bibliografía Nacional, vi, 1945, pp. 179-194.

Jehasse, Jean, La Renaissance de la critique. L'essor de l'Humanisme erudite de 1560 à 1614, Saint-Etienne, Publications de l'Université de Saint-Etienne, 1976.

Juárez, Encarnación, Italia en la vida y obra de Quevedo, New York, Peter Lang, 1990.

Kamen, Henry, Del Imperio a la decadencia. Los mitos que forjaron la España moderna, Madrid, Ediciones Temas de Hoy, 2006.

Lida, Raimundo, “De Quevedo, Lipsio y los Escalígeros», en su Letras hispánicas, México, Fondo de Cultura Económica, 1958, pp. 157-162.

Linde, Luis M., Don Pedro Girón, duque de Osuna. La hegemonía española en Europa a comienzos del siglo XVII, Madrid, Ediciones Encuentro, 2005.

Lipsio, Justo, Políticas, trad. Bernardino de Mendoza, Javier Peña Echeverría y Modesto Santos López, Madrid, Tecnos, 1997.

Lira Urquieta, Pedro, "Comentarios sobre Quevedo», en Sobre Quevedo y otros clásicos, Madrid, Ediciones Cultura Hispánica, 1958, pp. 27-86.

López Ruiz, Antonio, Tras las huellas de Quevedo (1971-2006), Almería, Ediciones Universidad de Almería, 2008.

Malvezzi, Virgilio, Historia de los primeros años del reinado de Felipe IV, ed. Donald L. Shaw, Londres, Tamesis Books, 1968.

Maravall, José Antonio, «Sobre el pensamiento social y político de Quevedo (una revisión)", Academia Literaria Renacentista. II Homenaje a Quevedo, Salamanca, Universidad de Salamanca, 1982, pp. 69-131.

Martínez Hernández, Santiago, Rodrigo Calderón, la sombra del valido. Privanza, favor y corrupción en la corte de Felipe III, Madrid, Centro de Estudios Europa Hispánica y Marcial Pons, 2009.

Müller, Franz-Walter, "Alegoría y realismo en los Sueños de Quevedo», en Francisco de Quevedo, ed. Gonzalo Sobejano, Madrid, Taurus, 1978, pp. 218241. 
Noticias de Madrid (1621-1627), ed. Ángel González Palencia, Madrid, Ayuntamiento de Madrid, 1942.

Novoa, Matías de, Memorias, en Codoin, t. LXI, Madrid, Imprenta de Miguel Ginesta, 1875.

Peraita, Carmen, Quevedo y el joven Felipe IV. El príncipe cristiano y el arte del consejo, Kassel, Reichenberger, 1997.

Pérez Bustamante, Ciriaco, "Quevedo, diplomático», Revista de Estudios Políticos, XIII, 1945, pp. 159-183.

Polibio, Historias, introd. A. Díaz Tejera, trad. Manuel Balasch Recort, Madrid, Gredos, 1991.

Quevedo, Francisco de, Discurso de las privanzas, ed. Eva María Díaz Martínez, Pamplona, Eunsa, 2000.

Quevedo, Francisco de, España defendida, ed. Victoriano Roncero, Pamplona, Eunsa, 2013.

Quevedo, Francisco de, Grandes anales de quince días. Historia de muchos siglos que pasaron en un mes, en Francisco de Quevedo, Obras completas en prosa, dir. Alfonso Rey, Madrid, Castalia, 2005, vol. III, pp. 57-115.

Quevedo, Francisco de, Política de Dios, Gobierno de Cristo, ed. Eva María Díaz Martínez, en Francisco de Quevedo, Obras completas en prosa. Tratados políticos, dir. Alfonso Rey, Madrid, Castalia, 2012, vol. v, pp. 161-326.

Ramírez, Alejandro, ed., Epistolario de Justo Lipsio y los españoles (1577-1606), Madrid, Castalia, 1966.

Roncero, Victoriano, Historia y política en la obra de Quevedo, Madrid, Editorial Pliegos, 1991.

Roncero, Victoriano, “Los Grandes anales de quince días: Literatura e Historia», Rilce, 9, 1993, pp. 56-72.

Roncero, Victoriano, “Un enigma historiográfico: el Mundo caduco y los Grandes analesm, Edad de Oro, 13, 1994, pp. 151-160.

Roncero, Victoriano, “Introdución», Francisco de Quevedo, Grandes anales de quince días. Historia de muchos siglos que pasaron en un mes, en Francisco de Quevedo, Obras completas en prosa, dir. Alfonso Rey, Madrid, Castalia, 2005, vol. III, pp. 45-56.

Roncero, Victoriano, “El valido y los validos en Quevedo», en L'Espagne des validos, Paris, Ellipses Editions, 2009, pp. 177-202.

Roncero, Victoriano, "Chile en Quevedo: el cuadro xxxvi de La Hora de todos y la Fortuna con seson, Anales de Literatura Chilena, 13, 11, Junio 2010, pp. 13-35.

Roncero,Victoriano, «Quevedo y el duque de Lerma (1606-1615)», en Jesús M. Usunáriz y Edwin Williamson, eds., La autoridad política y el poder de las letras en el Siglo de Oro, Madrid, Iberoamericana, 2013a, pp. 73-89.

Roncero, Victoriano, “Introducción», en Francisco de Quevedo, España defendida, Pamplona, Eunsa, 2013b, pp. 29-52.

Salazar, fray Juan de, Política española, ed. Miguel Herrero García, Madrid, Instituto de Estudios Políticos, 1945.

Salustio, Conjuración de Catilina-Guerra de Jugurta-Fragmentos de las «Historias», ed. Bartolomé Segura Ramos, Madrid, Gredos, 1997.

Schmidt, Bernhard, El problema español de Quevedo a Manuel Azaña, Madrid, Editorial Cuadernos para el Diálogo, 1976.

Serrano Poncela, Segundo, «Quevedo, hombre político (Análisis de un resentimiento)", en Formas de vida hispánica (Garcilaso-Quevedo-Godoy y los ilustrados), Madrid, Gredos, 1963, pp. 64-123. 
Sliwa, Krzysztof, Cartas, documentos y escrituras de Francisco Gómez de Quevedo y Villegas (1580-1645), Pamplona, Eunsa, 2005.

Tucídides, Historia de la Guerra del Peloponeso, ed. Francisco Romero Cruz, Madrid, Cátedra, $2005^{5}$.

Vera y Figueroa, Juan Antonio de, Fragmentos históricos de la vida de d. Gaspar de Guzmán, en Semanario erudito, ed. Antonio Valladares de Sotomayor, II, Madrid, 1787, pp. 145-296.

Villamediana, conde de, Poesía impresa completa, ed. José Francisco Ruiz Casanova, Madrid, Cátedra, 1990.

Vivar, Francisco, Quevedo y su España imaginada, Madrid, Visor libros, 2002. 


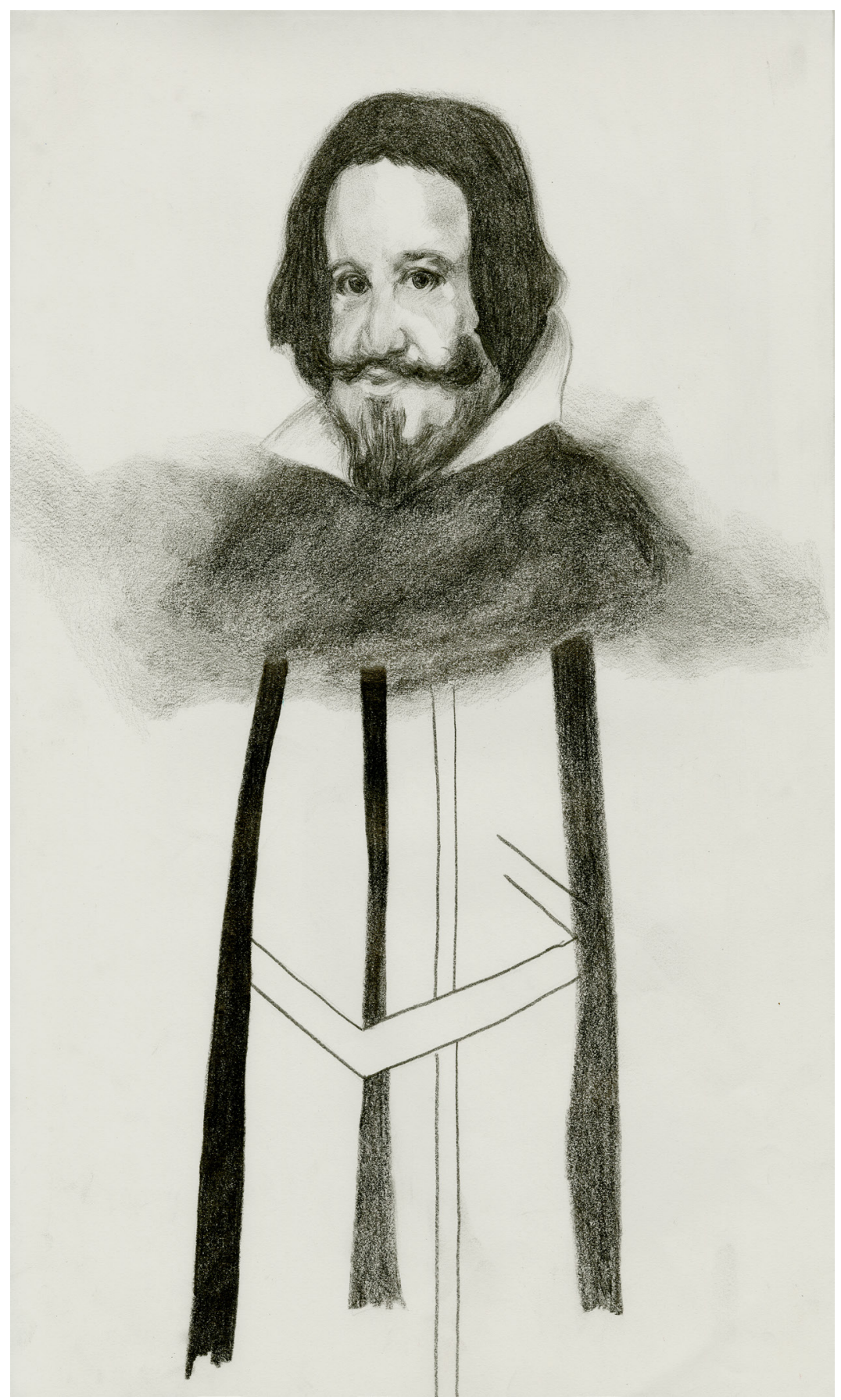


